\title{
Reassessing the impact of Food, Mating and Ageing on Callosobruchus maculatus' Fecundity, Oviposition and Longevity
}

\author{
Beck Arebamen Akhiwu* \\ Department of Plant Pathology, Nematology and Entomology, University of Idaho, Moscow, Idaho, USA
}

*Corresponding author: Beck Arebamen Akhiwu, Department of Plant Pathology, Nematology and Entomology, University of Idaho, Moscow, 132 Falls Avenue West, Apt C302, Twin Fall, Idaho, USA.

Received Date: August 07, 2020

Published Date: August 17, 2020

Abstract

Callosobruchus maculatus, commonly known as Bean weevil, is an agricultural insect pest of both field and storage crop in Africa, Asia and most parts of the world. They cause serious economic damage to cowpea seed and other leguminous crops throughout the tropical and subtropical world. Understanding the biology of $C$. maculatus is very important in the control of this insect pest. The aim of the study was to investigate the effects of feeding, mating, and aging on the fecundity and lifespan of the insect. C. maculatus was subjected to different feeding modes and mating. Daily weight was taken and recorded. The ability of ageing males to fertilize virgin females was investigated. This research is the first to investigate the effects of nutrients and ageing on the longevity and fecundity of $C$. maculatus. Data was collected and analyzed with tukey test at $5 \%$ significant difference. The results show that nutrient plays a vital role in longevity and fecundity of $C$. maculatus, and male $C$. maculatus would live longer in the absence of female. Furthermore, this study shows that weight loss and decline in reproductive ability (ageing males' ability to fertilize virgin females declines as they grow older) are some of the attributes of ageing in C. maculatus.

Keywords: Callosobruchus maculatus; Longevity; Fecundity; Virgin; Ageing; Mating

\section{Introduction}

Bruchids (Coleoptera; Bruchidae), especially those that belong to the genus Callosobruchus are pestiferous to stored seeds of many different legumes [1]. Bamaiyi et al., [2] reported that $C$. maculatus infest soya, bambara groundnuts Cicer arietinum, Lablab purpureus, Vigna acontifolia and Vigna radiate. Infestation may start on pods before harvest [3]. These infested pods may be carried over into the storage where they cause serious damage and loses. C. maculatus was reported to have caused 3\% annual cowpea damage in Nigeria in 1961 [4]. It is considered the most important field to storage insect pest of the cowpea plant [5].

Cowpea (Vigna unguiculata) is a widely adapted, stress tolerant grain legume from the genus Vigna. It is an important crop grown on about 7 million ha in warm to hot regions of Africa, Asia, and the Americas [6]. Developing countries depend on cowpea as a major source of protein for both human and livestock. Dry beans are a good source of plant-based protein and have been identified as a replacement for meat [7]. Beans contain about 21 to $25 \%$ protein by weight, which is much higher than other sources of vegetable protein [7]. Cowpea provides a good source of protein at a cheap cost compared to animal protein. Cowpea crops also provide other sources of nutrient such as calories, fat, carbohydrates, dietary fiber, minerals and vitamins in relatively large amounts. Therefore, it is very important to understand the biology, chemical ecology and behavior of this insect pest, C. maculatus, which causes a sig- 
nificant decrease in yield of cowpea [3]. Male and female C. maculatus are easily distinguished from one another by their general appearance. The most differentiating feature is the coloration of the plate covering the end of the abdomen. In the female, the plate is broad and darkly colored on both sides. In the male, the plate is smaller and lacks stripes. In some strains, females are larger in size than males. Also, females, are black in coloration and males are brown $[8,9]$. Adult C. maculatus do not require food or water for reproduction $[9,10]$. The eggs are strongly attached to the surface of the cowpea [4]. The larvae and pupae bore within the seed where they are only found $[4,11]$. Ageing is a universal characteristic of living things [12] and manifest as decreased reproductive ability, and increased probability of death due to physiological deteriorations [13]. The ability of organisms to survive declines as they age [14]. Studies have shown that male insects may sacrifice longevity for mating opportunities $[8,10]$. The antagonistic behavior among male insects has been suggested as a major reason for sex differences in mortality rate [15]. Though studies have investigated the cost of reproduction in C. maculatus [16] and multiple mating, lifetime fecundity and mortality of $C$. maculatus [17], specific factors that drive $C$. maculatus' longevity and population are not yet well explored. This study investigated the effect of feeding and mating on $C$. maculatus' reproduction and lifespan. The objectives of this study were to evaluate the effect of food and mating on C. maculatus fecundity and lifespan.

\section{Materials and Methods}

This study was conducted in the research laboratory of crop, soil and pest management department, Federal University of Technology Akure, under laboratory condition of $25^{\circ} \mathrm{C}-28{ }^{\circ} \mathrm{C}$ and 65 $75 \%$ relative humidity.

\section{Insect culture}

C. maculatus was cultured in kilner jars with mashed lid cover Laboratory procedure for culturing cowpea seed beetle described by Kaita et al., [18], was adopted in this study. Ife Brown bean, a well-known susceptible variety was used for culturing $C$. maculatus. Prior to the use of the cowpea seeds, the seeds were disinfested by deep-freezing for two weeks. We removed the seed from the freezer and allowed it to thaw at room temperature for 12-24 hours before using them for C. maculatus culturing.

\section{Experimental procedures}

Effects of food on C. maculatus longevity: Newly emerged male and female of age 1 day old were used in this study. A male and a female were placed separately inside a sampling bottle containing cotton wool with honey, and this honey served as source of food (nectar) for the insects. There were five replicates per treatments. A control treatment was also set-up in which case the insects were not fed with honey. Daily weight of the female and male C. maculatus were taken separately and recorded. Daily weight was recorded for a period of 5 days.
Effect of mating and food on longevity of $C$. maculatus: Newly emerged male and female of age 1 day old were used in this study. A male and a female were placed together in a sampling bottle containing cotton wool with honey, and this honey served as source of food (nectar) for the insects. There were five replicates per treatments. A control treatment was also set-up in which case the insects were not fed with honey. Daily weight of the female and male were $C$. maculatus were taken separately and recorded. Daily weights were taken for a period of 5 days.

Ability of ageing male to fertilize virgin male: Newly emerged female of age 1 day old were supplied with ageing virgin male of age day 3. A male and a female were placed together in a sampling bottle containing cotton wool with honey, and this honey served as source of food (nectar) for the insects. Controls were also set-up (a virgin female of age day 1 and a virgin male of age day 1). Numbers of eggs laid by the female were observed and counted daily for 5 days.

Analyses: Data were analyzed using SPSS. Counted data were transformed using square root transformation. The transformed data were subjected to tukey test at $5 \%$ significant different.

\section{Results}

This study shows that there was a significant difference between the adult weight of female $C$. maculatus subjected to different feeding and mating mode and control (Table 1). Table 2 shows mean weight of adult $C$. maculatus subjected to different mating and feeding mode. There was a significant difference between the weight of adult $C$. maculatus subjected to different feeding and mating mode from day 1-5. Mating without food was higher in day 1-3 (3.12, 2.62 and 1.56), while the body weights dropped from day $4-5$ (0.48 and 0.009). Feeding without mating show a consistent body weight from day $1-5(2.80,1.58,1.50,1.24$ and 0.98$)$. Table 3 show that there was a significant difference in number of eggs laid by the virgin female mated with ageing male (day $4=1.70$ and day $5=$ 1.23), there were no significant differences between 1-3 eggs laid (6.99, 5.66 and 4.02) by female. Table 4 show C. maculatus fecundity of young female and young male.

\section{Discussion}

This study quantified $C$. maculatus physiology (ageing) by measuring the daily body weight, numbers of eggs laid and ability of the male to fertilize the female. This study provides empirical evidence female $C$. maculatus, when fed with honey and supplied with a male, gained weight, but there was no effect on its longevity. This finding is somehow in agreement with similar studies by Paukku \& Kotiaho [16], who reported that male sperm may have a nutritional value for females. Since C. maculatus do not require food or water for reproduction or survival, Paukku and Kotiaho, suggested that female C. maculatus derive nutrient from male sperm during mating. This study shows that mating without feeding have no significant impact on female ageing and longevity. This finding (Table 2) 
show that male physiological processes can be influenced by food. Furthermore, the results of this study indicate that male $C$. maculatus maintain their weight when they feed on honey (nectar) and mate. However, longevity may be affected when they mate without food source. Adult male on diet without mating live ( 6 days) longer than adult male that is mating. This finding is in agreement with the study by Maklakov et al., [8], which indicated that male insects might sacrifice longevity for mating opportunities. Table 3 show that the ability of the male to fertilize female decreases as the male grows older. The numbers of eggs laid on age 1 day old were high-

\begin{tabular}{|c|c|c|c|c|c|}
\hline \multirow{2}{*}{ Treatments } & \multicolumn{5}{|c|}{ Mean Weights (g) } \\
\hline & Day 1 & Day 2 & Day 3 & Day 4 & Day 5 \\
\hline Food + mating & $1.98(a b)$ & $3.48(b)$ & $2.0(\mathrm{ab})$ & $1.18(a)$ & $0.64(a)$ \\
\hline Mating - food & $3.64(\mathrm{a})$ & $3.98(a)$ & $2.72(a)$ & $1.6(a)$ & $0.44(\mathrm{a})$ \\
\hline Food-mating & $3.32(b)$ & $2.28(a b)$ & $1.98(a b)$ & $1.46(\mathrm{ab})$ & $0.84(\mathrm{a})$ \\
\hline Control (no food, no mating) & $2.34(\mathrm{~b})$ & $2.56(\mathrm{~b})$ & $2.40(\mathrm{~b})$ & $1.24(\mathrm{a})$ & $0.22(a)$ \\
\hline
\end{tabular}

Mean in each column bearing the same letters are not significantly different at $5 \%$ level of probability by Tukey test.

Table 2: Mean daily weight of adult male C. maculatus subjected to different treatments.

\begin{tabular}{|c|c|c|c|c|c|}
\hline \multirow{2}{*}{ Treatments } & \multicolumn{5}{|c|}{ Mean Weights (g) } \\
\hline & Day 1 & Day 2 & Day 3 & Day 4 & Day 5 \\
\hline Food + mating & $2.04(\mathrm{bc})$ & $2.20(\mathrm{~b})$ & $1.35(\mathrm{ab})$ & $1.00(\mathrm{a})$ & $0.56(a)$ \\
\hline Mating - food & $3.12(a)$ & $2.62(\mathrm{a})$ & $1.56(\mathrm{a})$ & $0.48(\mathrm{ab})$ & $0.009(\mathrm{a})$ \\
\hline Food-mating & $2.80(\mathrm{~b})$ & $1.58(\mathrm{c})$ & $1.50(\mathrm{~b})$ & $1.24(\mathrm{a})$ & $0.98(a)$ \\
\hline Control (no food, no mating) & $2.90(\mathrm{~b})$ & $1.40(\mathrm{bc})$ & $1.10(\mathrm{~b})$ & $0.36(\mathrm{ab})$ & $0.10(\mathrm{a})$ \\
\hline
\end{tabular}

Mean in each column bearing the same letters are not significantly different at $5 \%$ level of probability by Tukey test.

Table 3: Mean of the daily numbers of eggs laid by virgin female mated with ageing male C. maculatus (data were transformed using square root transformation)

\begin{tabular}{|r|r|}
\hline Days & No of Eggs Laid \\
\hline 1 & $6.99(\mathrm{c})$ \\
\hline 2 & $5.66(\mathrm{bc})$ \\
\hline 3 & $4.02(\mathrm{~b})$ \\
\hline 4 & $1.70(\mathrm{a})$ \\
\hline 5 & $1.23(\mathrm{a})$ \\
\hline
\end{tabular}

Mean in each column bearing the same letters are not significantly different at $5 \%$ level of probability by Tukey test.

Table 4: Mean of the daily numbers of eggs laid by young virgin female mated with young virgin male $\mathrm{C}$. maculatus (data were transformed using square root transformation).

\begin{tabular}{|r|r|}
\hline Days & No of Eggs Laid \\
\hline 1 & $17.68(\mathrm{c})$ \\
\hline 2 & $16.6(\mathrm{bc})$ \\
\hline 3 & $15.10(\mathrm{~b})$ \\
\hline 4 & $9.02(\mathrm{a})$ \\
\hline 5 & $8.76(\mathrm{a})$ \\
\hline
\end{tabular}

Mean in each column bearing the same letters are not significantly different at $5 \%$ level of probability by Tukey test.

\section{Acknowledgment}

The author kindly acknowledges Dr. Joy Idoko and her laboratory for allowing me to use her space for this study.

\section{Conflict of Interest}

No conflict of interest. 


\section{References}

1. Ofuya TI (1995) Multiple mating and its consequences in males of Callosobmchus maculatus (F.) (Coleoptera: Bruchidae). Journal of Stored Products Research 31: 71-75.

2. Bamaiyi LJ, Onu I, Amatobi CI, Dike MC (2006) Effect of Callosobruchus maculatus infestation on nutritional loss on stored cowpea grains. Archives of Phytopathology and Plant Protection 39: 119-127.

3. Ojimelukwe PC, Ogwumike FC (1999) Effects of infestation by bruchid beetles (Callosobruchus maculatus) on the nutritional quality and sensory properties of cowpeas (Vigna unguiculata). Journal of Food Biochemistry 23: 637-645.

4. Prevett PF (1961) Field infestation of cowpea (Vigna unguiculata) pods by beetles of the families Bruchidae and Curculionidae in northern Nigeria. Bulletin of Entomological Research 52(4): 635-645.

5. Anon (1980) International Institute of Tropical Agriculture. Research Search Lights for 1979: 43-45.

6. Ehlers JD, Hall AE (1997) Cowpea (Vigna unguiculata L. Walp). Field Crops Research 53(1-3): 187-204.

7. Multari S, Stewart D, Russell WR (2015) Potential of fava bean as future protein supply to partially replace meat intake in the human diet Comprehensive Reviews in Food Science and Food Safety 14: 511-522.

8. Maklakov AA, Bonduriansky R (2009) Sex differences in survival costs of homosexual and heterosexual interactions: evidence from a fly and a beetle. Animal Behavior 77: 1375-1379.

9. Ramaswamy SB, Monroe WA (1997) Putative chordotonal organ in the fore coxae of adult Callosobruchus maculatus and C. subinnotatus (Coleoptera: Bruchidae). Annals of the Entomological Society of America 90: 806-809.
10. Maklakov AA, Bonduriansky R, Brooks RC (2009) Sex differences, sexual selection, and ageing: An experimental evolution approach. Society for the Study of Evolution 63: 2491-2503.

11. Vats Lk (1974) Distintive characters of larvae of three species of Callosobruchus Pic (Bruchidae: Colleoptera) together with a key fosr their identification. Indian Journal of Entomology 36: 17-22.

12. Anderson E (2008) Cognitive change in old age. In: R Jacoby, C Oppenheimer, T Dening, A Thomas (Eds.), Oxford textbook of old age psychiatry (1st ed.,). Oxford: Oxford University Press, pp. 33-50.

13. Rose MR, Flat T, Graves JL, Greer LF, Martinez DE, et al. (2012) What is aging? Frontiers in Genetics 3: 134.

14. Raamsdonk VM (2018) Mechanisms underlying longevity: A genetic switch model of aging. Experimental Gerontology 107: 136-139.

15. Kokko H (2005) Treat 'em mean, keep 'em (sometimes) keen: Evolution of female preferences for dominant and coercive males. Evolutionary Ecology 19: 123-135.

16. Paukku S, Kotiaho JS (2005) Cost of reproduction in Callosobruchus maculatus: effects of mating on male longevity and the effect of male mating status on female longevity. Journal of Insect Physiology 51: $1220-1226$.

17. Fox CW (1993) Multiple mating, lifetime fecundity and female mortality of the bruchid beetle, Callosobruchus maculatus (Coleoptera: Bruchidae). Bristish Ecological Society 7: 203-208.

18. Keita MS, Vincent C, Schmit JP, Ramaswamy S, Belanger A (2000) Effect of various essential oils on Callosobruchus maculatus (F.) (Coleoptera: Bruchidae). Journal of Stored Products Research 36: 355-364. 